\title{
KEDUDUKAN HUKUM ITSBAT NIKAH POLIGAMI SIRRI
}

\author{
Ahmad Cholid Fauzi \\ Magister Hukum Universitas Semarang
}

\begin{abstract}
ABSTRAK
Penelitian ini bertujuan untuk menganalisas kedudukan hukum Itsbat nikah poligami irri. Itsbat nikah poligami sirri adalah permohonan penetapan nikah yang diajukan ke Pengadilan Agama untuk dinyatakan mengenai sahnya pernikahan kedua dan seterusnya yang dilakukan secara sirri tidak dicatatkan sehingga memiliki kekuatan dan kepastian hukum. Jenis pendekatan tesis ini adalah penelitian yuridis normatif artinya hukum dikonsepsikan sebagai apa yang tertulis dalam peraturan perundangundangan (law in book). Hasil penelitian menunjukan dikabulkannya permohonan itsbat nikah poligami sirri dalam putusan Pengadilan Agama Magetan nomor 445/Pdt.G/2012/PA.Mgt. Putusan tersebut tergolong hukum materiil baru. Dengan demikian legal standing terhadap putusan tersebut akan menjadi yurisprudensi, melalui itsbat nikah poligami sirri dari Pengadilan Agama Magetan, perkawinan tersebut telah mempunyai kekuatan dan kepastian hukum. Adapun solusi terhadap putusan tersebut yaitu perlu adanya payung hukum terhadap kebolehan itsbat nikah poligami sirri, adanya penyuluhan sosialisasi tentang pentingnya pencatatan nikah (nikah resmi) dan prosedur izin poligami.
\end{abstract}

Keywords : Kedudukan hukum; itsbat nikah; poligami sirri 


\title{
THE POSITION OF LAWS ITSBAT NIKAH POLIGAMI SIRRI
}

\author{
Ahmad Cholid Fauzi \\ Master of Law, University of Semarang
}

\begin{abstract}
This study aims to analyze the legal position of Itsbat marriage of polygamous irri marriage. Itsri sirri polygamy marriage is a marriage application submitted to the Religious Court to be approved regarding the legitimacy of a second marriage and so on which is carried out by unregistered sirri so that it has the power and legal certainty. This type of thesis question is a normative juridical study of legal intentions conceived of as what is written in the legislation. The results showed that the application for the Sirri polygamy marriage was granted in the Magetan Religious Court ruling number 445 / Pdt.G / 2012 / PA.Mgt. The decision was classified as a new material law. Thus the legal position of this ruling will become jurisprudence, through the marriage of Sirri polygamy marriage from the Magetan Religious Court, this marriage has strength and legal certainty. As a solution to this decision, a legal umbrella is required for permissibility of the Sirri polygamy marriage, there is a briefing on the importance of registration of marriage (official marriage) and procedures for licensing polygamy.
\end{abstract}

Keywords: Legal position; marriage law; poligami sirri 


\section{A. PENDAHULUAN}

Islam mengatur hubungan individu dengan aturan yang sangat suci dan menjadikannya mulia derajatnya, ada hubungan persaudaraan, ada hubungan persahabatan bahkan hubungan perkawinan, hubungan pernikahan termasuk pernikahan poligami tentunya adalah hubungan yang sangat kuat didalam Islam ( Mitsaqon Holidzon ) untuk menuju rumah tangga yang sakinah, mawaddah warohmah serta melahirkan Durriyatan toyyibah (keturunan yang baik ). ${ }^{1}$ Ajaran perkawinan termasuk perkawinan poligami didalam Islam bukan sekedar untuk kepuasan biologis kaum laki-laki, melainkan juga untuk pewarisan nilainilai guna melanggengkan peradaban dunia.

Praktek perkawinan poligami yang ada di tengah-tengah masyarakat terdapat banyak ragam dan bentuk dalam pelaksanaanya, ada pernikahan poligami yang memang telah mendapatkan izin dari Pengadilan Agama resmi melalui prosedur yang ditetapkan oleh Undang-undang, namun tidak sedikit pula praktek perkawinan poligami yang dilakukan secara sirri (pernikahan poligami yang tidak memperoleh izin dari Pengadilan Agama sehingga tidak dicatatkan), trend pernikahan poligami sirri ini dewasa ini telah banyak kita jumpai di antaranya pernikahan poligami sirri Murdiono, syekh puji , bahkan poligami sirri mantan bupati Garut Aceng Fikri, itu semua adalah contoh-contoh perkawinan poligami sirri yang tidak prosedural menurut hukum namun terjadi di Indonesia. Oleh karenanya perkawinan poligami siri semacam itu pada akhirnya membawa dampak yang luar biasa bukan saja bagi

pelaku pernikahan poligami sirri, melainkan juga bagi anak-anak keturunannya sebab pada titik waktu tertentu sang anak yang lahir dari akibat perkawinan poligami sirri tersebut akan mencari dan meminta status hukum atas dirinya, kepastian hukum siapa bapaknya, dan bila kondisi sudah demikian ini pada ujungnya sang ayah dan ibu yang merupakan pasangan pernikahan poligami sirri tersebut mengajukan permohonan Itsbat nikah poligami sirri (penetapan pengesahan kawin poligami yang tidak tercatat) ke Pengadilan

${ }^{1}$.Agus Mustofa, Poligami Yuuk,Benarkah Al-qur.an menyuruh poligami karena alasan syahwat, Padma press, Surabaya,Tahun 2013, hlm.4. 
Agama guna memperoleh status/kepastian hukum tentang sahnya perkawinan poligami sirri yang mereka lakukan. Hal ini sebagaimana kasus permohonan Itsbat nikah poligami sirri yang diajukan di Pengadilan Agama Magetan tersebut Persoalannya adalah apakah ada hukum materiil Pengadilan Agama yang mengatur tentang Itsbat nikah poligami sirri sebagaimana yang dimaksud? Sebab sesuai uraian diatas penjelasan pasal 49 ayat 2 aitem 22 Undang-undang nomer 7 tahun 1989 tentang Peradilan Agama tidak mengatur perihal Itsbat nikah poligami sirri, padahal dilapangan secara riil banyak ditemukan kasuskasus demikian, sehingga lahir sebuah putusan Pengadilan Agama Magetan nomor 445/Pdt.G/2012/PA.Mgt yang mengabulkan Itsbat nikah poligami sirri artinya perkawinan poligami sirri yang dilakukan pasangan Sujarno bin Hardjo Paimin dengan seorang wanita bernama Yuni Diana binti Hartono dinyatakan sah menurut hukum oleh Pengadilan Agama Magetan.

Berdasarkan pemaparan latar belakang diatas, Penulis hendak membahasnya dalam bentuk karya tulis tesis dengan judul:

“KEDUDUKAN HUKUM ITSBAT NIKAH POLIGAMI SIRRI (DALAM KAJIAN TERHADAP PUTUSAN PENGADILAN AGAMA MAGETAN NOMOR : 445/Pdt.G/2012/PA.Mgt ). Dengan harapan melalui penelitian ini dapat diketahui kedudukan hukum Itsbat nikah poligami sirri itu sendiri.

\section{B. RUMUSAN MASALAH}

Berdasarkan rumusan masalah di atas, maka tujuan dalam penelitian ini adalah sebagai berikut:

1. Bagaimana kedudukan landasan hukum putusan Pengadilan Agama Magetan nomor : 445/Pdt.G/2012/PA. Mgt?

2. Bagaimana konsekuensi yang ditimbulkan dan solusi atas putusan Pengadilan Agama Magetan nomor : 445/Pdt.G/2012/PA. Mgt ? 


\section{METODE PENELITIAN}

Metode penelitian adalah suatu cara atau sistem untuk mengerjakan sesuatu secara sistematik dan metodologi adalah ilmu pengetahuan yang mempelajari proses berfikir, analis berfikir serta mengambil kesimpulan yang tepat dalam suatu penelitian. ${ }^{2}$ Jadi metode ini merupakan langkah-langkah dan cara yang sistematis, yang akan ditempuh oleh seseorang dalam suatu penelitian dari awal hingga pengambilan kesimpulan.

1. Pendekatan Penelitian

Pendekatan penelitian tesis ini adalah pendekatan yuridis normatif artinya hukum dikonsepsikan sebagai apa yang tertulis dalam peraturan perundangundangan ( law in book) atau hukum dikonsepsikan sebagai kaidah atau norma yang merupakan patokan berprilaku bagi manusia yang dianggap pantas sebagai haknya. ${ }^{3}$ dengan mengkaji apa norma hukum yang di gunakan oleh hakim pengadilan agama Magetan dalam mengadili perkara permohonan Itsbat nikah poligami sirri dengan mengkaji dokumen-dokumen (library document) putusan pengadilan agama Magetan terkait dengan perkara tersebut.

Dari putusan tersebut penulis memfokuskan pada "KEDUDUKAN HUKUM ITSBAT NIKAH POLIGAMI SIRRI (KAJIAN TERHADAP PUTUSAN PENGADILAN AGAMA MAGETAN NOMOR : 445/Pdt.G/2012/PA.Mgt TENTANG ITSBAT NIKAH POLIGAMI SIRRI)

Data yang digunakan dalam penelitian ini adalah data sekunder, sedangkan data sekunder diperoleh dari bahan pustaka.

\section{PEMBAHASAN}

\section{KEDUDUKAN LANDASAN HUKUM TERHADAP PERKARA NOMOR : 445/Pdt. G/2012/PA.Mgt}

2 Soerjono Soekamto, Penelitian Hukum Normatif Suatu Tinjauan Singkat, (Jakarta: Raja Grafinda Persada, 2001), hal 3.

${ }^{3}$.Amirudin, dan H.Zainal Asikin, Pengantar metode penelitian hukum, Raja Grafindo persada, Jakarta, hlm. 118. 
Sebagimana putusan nomor : 445/Pdt.G/2012/PA. Mgt, bahwa Pengadilan Agama Magetan Jawa Timur telah memutus perkara permohonan Isbat poligami sirri yang diajukan oleh Pemohon (SUJARNO bin HARDJO PAIMIN) dan YUNI DIANA bin HARTONO,

\section{E L A W A N ;}

SUKARTINAH binti ISKANDAR, istri pertama sebagai : TERMOHON, dan dalam putusannya Majels Hakim dalam hal ini mengadilii dengan amar putusan sebagai berikut :

\section{E N G A D I L I}

1. Mengabulkan permohonan para Pemohon ;

2. Menetapkan sah pernikahan poligami siri Pemohon I ( SUJARNO bin HARDO PAIMIN ) dengan Pemohon II ( YUNI DIANA binti HARTONO ) yang dilaksanakan pada bulan Agustus 2010 ;

3. Membebankan kepada Pemohon untuk membayar biaya perkara ini sebesar $\quad$ Rp. 316.000,-- (tiga ratus enam belas ribu rupiah),

Berdasarkan analisis diatas dapat dipahami bahwa putusan Pengadilan Agama Magetan nomor 445/Pdt.G/2012/PA.Mgt merupakan terobosan hukum mataril baru. karena jelas-jelas dalam prespektif undang-undang hal tersebut menjelaskan secara tegas bahwa permohonan itsbat nikah poligami sirri tidak di temukan.

Menurut penelitian ini, hakim mengabulkan perkara itsbat nikah poligami sirri berdasarkan beberapa hal, diantaranya :

a) Teori Keadilan

Dalam Islam, poligami didefinisikan sebagai perkawinan seorang suami dengan isteri lebih dari seorang dengan batasan maksimal empat orang isteri dalam waktu yang bersamaan. Batasan ini didasarkan pada QS. al-Nisa (4): 3 yang berbunyi:

"Dan jika kamu takut tidak akan dapat berlaku adil terhadap (hakhak) perempuan yatim (bilamana kamu mengawininya), maka kawinilah wanitawanita (lain) yang kamu senangi: dua, tiga atau empat. Kemudian jika kamu takut tidak akan dapat berlaku adil, maka (kawinilah) seorang saja, atau budak- 
budak yang kamu miliki. Yang demikian itu adalah lebih dekat kepada tidak berbuat aniaya."

Pegertian hukum yaitu hakikat hukum, ialah menjadi sarana bagi penciptaan suatu aturan masyarakat yang adil. Sedangkan hakikat hukum ialah membawa aturan yang adil dan dalam masyarakat ( rapport du droit, inbreng van recht $){ }^{4}$

Demikian halnya, pernikahan poligami sirri antara Pemohon I dan Pemohon II telah dilakukan menurut ketentuan hukum Islam, dan telah mendapatkan ijin dan persetujuan isteri pertama, serta tidak mempunyai halangan pernikahan menurut prinsip Undang-Undang Nomor 1 tahun 1974 maupun Kompilasi Hukum Islam; karena itu Majelis hakim sepakat mengabulkan permohonan isbat nikah poligami sirri pemohon.

Dalam perkawinan poligami kewajiban untuk memelihara dan memberikan keperluan hidup bagi isteri-isteri dan anak-anaknya adalah tanggungan suami yang telah melangsungkan perkawinan poligami. Antara isteri yang satu dengan isteri yang lainnya seorang suami harus berlaku adil dalam hal pemberian nafkah lahir.

Demikian juga halnya dalam pemeliharaan dan pendidikan anak-anaknya, seorang ayah harus berlaku adil terhadap anak-anak yang lahir dari masingmasing isteri, yang merupakan salah satu syarat dalam melaksanakan poligami.

b) Teori Kepastian Hukum

Teori kepastian hukum, menurut Soerjono Soekanto adalah Wujud kepastian hukum yaitu peraturan-peraturan dari pemerintah pusat yang berlaku umum diseluruh wilayah negara. Kemungkinan lain adalah peraturan tersebut berlaku umum, tetapi bagi golongan tertentu, selain itu dapat pula peraturan setempat, yaitu peraturan yang dibuat oleh penguasa setempat yang hanya berlaku di daerahnya saja, misalnya peraturan kotapraja. ${ }^{5}$

Arti penting kepastian hukum menurut Soedikno Mertokusumo bahwa masyarakat mengharapkan adanya kepastian hukum karena dengan adanya

${ }^{4}$ Ibid. hlm. 77

${ }^{5}$ Soerjono Soekanto, op.cit, hlm. 56 
kepastian hukum, masyarakat akan lebih tertib. Hukum bertugas menciptakan kepastian hukum karena bertujuan untuk ketertiban masyarakat. tanpa kepastian hukum, orang tidak tau apa yang harus diperbuatnya sehingga akhirnya timbul keresahan. Tetapi jika terlalu menitik beratkan pada kepastian hukum dan ketat menaati peraturan hukum, maka akibatnya akan kaku serta menimbulkan rasa tidak adil.

Adapun yang terjadi peraturannya tetap demikian, sehingga harus ditaati atau dilaksanakan. Undang-undang itu sering terasa kejam apabila dilaksanakan secara ketat, lex dure, sed tamen scripta (Undang-undang itu kejam, tapi memang demikianlah bunyinya). ${ }^{6}$

Tujuan hukum memang tidak hanya keadilan, tetapi juga kepastian hukum dan kemanfaatan. Idealnya, hukum memang harus mengakomodasikan ketiganya. Putusan hakim, misalnya, sedapat mungkin merupakan resultante dari ketiganya. ${ }^{7}$

\section{c) Teori Administrasi}

Teori administarasi publik adalah serangkaian konsep yang berhubungan dengan masalah publik yang telah diuji kebenarannya melalui riset untuk mencapai tujuan secara efektif dan efisien. Teori ini menggambarkan perubahan-perubahan dalam arah kebijakan publik dengan mengeksploitasi birokrasi. Teori administrasi yang mengedepankan birokrasi yang transparan menuntut seseorang untuk menempuh jalur hukum. Hal itu yang dilakukan oleh pemohon I dan II untuk mengajukan permohonan itsbat nikah poligami sirri. Dengan tujuan perkawinannya dinyatakan sah menurut hukum sesuai pasal Pasal 2 ayat (1) Undang-Undang Perkawinan, Pasal 2 ayat 1. serta, perkawinannya dapat dicatatkan sesuai Pasal 2 ayat (2) yang menyebutkan bahwa tiap-tiap perkawinan dicatat menurut peraturan perundangundangan yang berlaku.

Dengan demikian legal standing terhadap putusan itsbat nikah poligami sirri menjadi yurisprudensi. Yurisprudensi merupakan keputusan-keputusan dari hakim terdahulu

${ }^{6}$ Sudikno Mertokusumo, 1988, Mengenal Hukum (Suatu Pengantar), Liberty, Yogyakarta hlm. 136

${ }^{7}$ Darji Darmodiharjo dan Shidarta, 2008, Pokok-pokok Filsafat Hukum Apa dan Bagaimana Filsafat Hukum di Indonesia, PT. Gramedia Pustaka Utama, Jakarta., hlm. 155 
untuk menghadapi suatu perkara yang tidak diatur di dalam UU dan dijadikan sebagai pedoman bagi para hakim yang lain untuk menyelesaian suatu perkara yang sama.

\section{KONSEKUENSI YANG DITIMBULKAN DAN SOLUSI ATAS PUTUSAN PENGADILAN AGAMA MAGETAN NOMOR : 445/Pdt.G/2012/PA.Mgt}

Fungsi dan kedudukan pencatatan perkawinan menurut Bagir Manan adalah untuk menjamin ketertiban hukum (legal order) yang berfungsi sebagai instrumen kepastian hukum, kemudahan hukum, disamping sebagai salah satu alat bukti perkawinan. ${ }^{8}$ Oleh karena itu, jika terjadi pasangan yang telah melakukan perkawinan yang sah menurut agama, tetapi belum dicatat, maka menurut Bagir Manan cukup dilakukan pencatatan. Jika pasangan itu diharuskan melakukan akad nikah lagi, maka hal itu bertentangan dengan Pasal 2 ayat (1), akibatnya perkawinan yang baru menjadi tidak sah.

Dengan adanya pencatatan perkawinan, maka akibat hukumnya perkawinan dianggap sah apabila memenuhi dua syarat, yaitu :

1) Telah memenuhi ketentuan hukum materil, yaitu telah dilakukan dengan memenuhi syarat dan rukun menurut hukum Islam.

2) Telah memenuhi ketentuan hukum formil, yaitu telah dicatatkan pada Pegawai Pencatat Nikah yang berwenang.

Itsbat nikah punya implikasi memberikan jaminan lebih konkret secara hukum atas hak anak dan isteri dalam perkawinan tersebut dan juga apabila pasangan suami isteri tersebut bercerai. Atau dengan kata lain itsbat nikah sebagai dasar hukum dari pencatatan perkawinan yang melahirkan kepastian hukum terhadap status perkawinan, status anak serta harta benda dalam perkawinan. Adapun solusi terhadap putusan Pengadilan Agama Magetan dalam perkara nomor : 445/Pdt.G/2012/PA/Mgt. Yang mengabulkan permohonan isbat nikah poligami sirri, sebagai berikut:

a. Perlu adanya payung hukum terhadap kekosongan hukum itsbat nikah mengenai kebolehan itsbat nikah poligami sirri yang terjadi setelah berlakunya Undang-undang Perkawinan, karena semakin banyaknya perkawinan yang

${ }^{8}$ Abdul Manan, Aneka Masalah Hukum Perdata Islam di Indonesia, Prenada Media Group, Jakarta, 2008, Hal. 159 
tidak tercatat yang merugikan pihak isteri dan anak yang lahir dari perkawinan di bawah tangan.

b. Adanya penyuluhan sosialisasi tentang pentingnya pencatatan nikah (nikah resmi), sah secara agama sekaligus mendapatkan perlakuan dan perlindungan hukum sebagaimana yang dikehendaki pasal 2 ayat 1 dan2 UUP No. 1 Thn 1974. Penyuluhan pada masyarakat tentang hal ini harus terus digalakan secara terpadu dengan melibatkan para pihak dan instansi yang berkompeten

c. Adanya sosialisasi tentang prosedur izin poligami berdasarkan Undangundang Perkawinan No 1 Tahun 1974 tentang Perkawinan, Peraturan Pemerintah No 9 Tahun 1975 tentang Pelaksanaan Undang-undang No 1 Tahun 1974 tentang Perkawinan dan Kompilasi Hukum Islam (KHI) bagi penganut agama Islam. Sosialisasi ini bertujuan agar masyarakat tertib administrasi dan taat hukum

d. Harus ada penyuluhan ke desa-desa seperti melalui pengajian-pengajian selalu disinggung tentang pentingnya pencatatan nikah agar masyarakat tahu akan pentingnya pencatatan nikah. Sekaligus untuk menghindari berbagai kemungkinan negatif yang terjadi, seperti perebutan warisan dan pengakuan anak, dll.

\section{E. PENUTUP}

Bahwa nikah poligami sirri dalam prespektif hukum islam (fiqh) dapat dibenarkan sepanjang pelaksanaan nikah poligami sirri tersebut memenuhi syaratsyarat dan rukun nikah didalam Islam, hal itu sejalan dengan maksud pasal 2 ayat 1 undang-undang nomor 1 tahun 1974 tentang perkawinan yang menyatakan bahwa perkawinan sah apabila dilaksanakan menurut hukum agama dan atau kepercayaan masing-masing, sehingga perkawinan poligami sirri dapat diajukan permohonan pengesahan nikah (isbat nikah) ke Pengadilan Agama sesuai dengan maksud pasal 7 ayat 2 Kompilasi Hukum Islam yang menyatakan bahwa dalam hal perkawinan tidak dapat dibuktikan dengan akta nikah dapat diajukan isbat nikahnya ke pengadilan agama oleh karena itu putusan Pengadilan Agama 
Magetan nomor 445/Pdt.G/2012/PA.Mgt yang mengabulkan permohonan isbat nikah poligami sirri sejalan dengan ketentuan pasal 2 ayat 1 undang-undang nomor 1 tahun 1974 tentang perkawinan dan pasal 7 ayat 2 Kompilasi Hukum Islam. Dengan demikian legal standing terhadap putusan itsbat nikah poligami sirri menjadi yurisprudensi. Yurisprudensi adalah keputusan-keputusan dari hakim terdahulu untuk menghadapi suatu perkara yang tidak diatur di dalam UU dan dijadikan sebagai pedoman bagi para hakim yang lain untuk menyelesaian suatu perkara yang sama. Yurisprudensi diciptakan berdasarkan UU No. 48 Tahun 2009 Mengenai Kekuasaan Kehakiman, UU ini menyatakan : pengadilan tidak boleh menolak untuk memeriksa perkara, mengadili perkara dan memutuskan perkara yang diajukan dengan alasan hukum tidak ada atau kurang jelas (kabur), melainkan wajib memeriksa serta mengadilinya. Hakim diwajibkan untuk menggali, mengikuti dan memahami keadilan dan nilai-nilai hukum yang tumbuh dan berkembang di dalam masyarakat

Setelah dikabulkannya itsbat nikah, implikasinya terhadap status perkawinan dimana perkawinan tersebut telah mempunyai kekuatan hukum. Begitu pula anak-anak yang dilahirkan dari perkawinan tersebut mendapat pengakuan Negara, dimana anak-anak tersebut berhak atas harta warisan dari bapaknya. Selain itu, harta yang diperoleh sejak berlangsungnya perkawinan merupakan harta bersama. Dengan demikian pencatatan perkawinan merupakan persyaratan formil sahnya perkawinan, persyaratan formil ini bersifat procedural dan administratif. Itsbat nikah punya implikasi memberikan jaminan lebih konkret secara hukum atas hak anak dan isteri dalam perkawinan tersebut dan juga apabila pasangan suami isteri tersebut bercerai. Atau dengan kata lain itsbat nikah sebagai dasar hukum dari pencatatan perkawinan yang melahirkan kepastian hukum terhadap status perkawinan, status anak serta harta benda dalam perkawinan. Perlu adanya payung hukum terhadap kekosongan hukum itsbat nikah mengenai kebolehan itsbat nikah poligami sirri yang terjadi setelah berlakunya Undangundang Perkawinan. 


\section{DAFTAR PUSTAKA}

\section{Buku}

Abdul Manan, Aneka Masalah Hukum Perdata Islam di Indonesia, Prenada Media Group, Jakarta, 2008

Agus Mustofa, Poligami Yuuk,Benarkah Al-qur.an menyuruh poligami karena alasan syahwat, Padma press, Surabaya,Tahun 2013. Amirudin, dan H.Zainal Asikin, Pengantar metode penelitian hukum, Raja Grafindo persada, Jakarta

Darji Darmodiharjo dan Shidarta, 2008, Pokok-pokok Filsafat Hukum Apa dan Bagaimana Filsafat Hukum di Indonesia, PT. Gramedia Pustaka Utama, Jakarta.

Soerjono Soekamto, Penelitian Hukum Normatif Suatu Tinjauan Singkat, (Jakarta: Raja Grafinda Persada, 2001)

Sudikno Mertokusumo, 1988, Mengenal Hukum (Suatu Pengantar), Liberty, Yogyakarta 